\title{
Growth in Skull Length and Width of the Arctic Wolf: Comparison of Models and Ontogeny of Sexual Size Dimorphism
}

\author{
NICHOLAS C. LARTER, ${ }^{1}$ JOHN A. NAGY² and TAD M. BARTAREAU ${ }^{3}$
}

(Received 10 May 2011; accepted in revised form 12 December 2011)

\begin{abstract}
We compared four classical nonlinear growth curves (Gompertz, Logistic, Richards, and von Bertalanffy) in modeling observed skull condylobasal length and zygomatic width as a function of age in wild arctic wolves (Canis lupus arctos). We analyzed gender-specific growth patterns and the ontogeny of sexual size dimorphism in this species as revealed by the best model from these alternatives. For both genders and skull size measurements, the size-at-age data provided the best support for the von Bertalanffy model because of higher fitting degrees, lower root mean squared standard deviation of data points about the fitted growth curve, Akaike weight of $37.4 \%$ or higher, and fewer parameters derived directly from metabolic laws. Male asymptotic condylobasal length was 3.2\% longer, and zygomatic width $4.1 \%$ wider, than in females. Sexual size dimorphism in this species develops in part because males grow faster, which might benefit them in terms of reproductive success and the capture and killing of large ungulate prey.
\end{abstract}

Key words: Canis lupus, Canadian Arctic Archipelago, growth model, sexual dimorphism, skull, von Bertalanffy, wolf

RÉSUMÉ. Nous avons comparé quatre courbes de croissance non linéaires classiques (Gompertz, logistique, Richards et von Bertalanffy) se rapportant à la modélisation de la longueur condylobasale de crânes observés et à leur largeur zygomatique en fonction de l'âge chez les loups arctiques sauvages (Canis lupus arctos). Ensuite, nous avons analysé les tendances de croissance en fonction de la sexospécificité et de l'ontogenèse de dimorphisme sexuel chez cette espèce, tel que révélé par le meilleur de ces modèles. Dans le cas des données relatives au sexe et aux mesures de tailles de crânes, les données propres aux tailles selon l'âge ont fourni le meilleur support pour le modèle de von Bertalanffy en raison de degrés de raccord plus élevés, d'un écart-type moyen inférieur des points de données sur la courbe de croissance ajustée, d'un poids Akaike de $\geq 37,4 \%$ et de moins de paramètres directement dérivés des lois métaboliques. La longueur condylobasale asymptotique du mâle était de 3,2 \% plus prononcée et sa largeur zygomatique était de 4,1\% plus grande que celles de la femelle. Chez cette espèce, le dimorphisme sexuel se développe en partie parce que les mâles grandissent plus vite, ce qui pourrait avantager les mâles en matière de réussite de reproduction, de même que les aider à capturer et à tuer les grosses proies ongulées.

Mots clés : Canis lupus, archipel arctique canadien, modèle de croissance, dimorphisme sexuel, crâne, von Bertalanffy, loup

Révisé pour la revue Arctic par Nicole Giguère.

\section{INTRODUCTION}

Growth, a primary element in describing the basic biology and ecology of all species (Lawrence, 1980), is related to important life-history traits such as size and age at maturity (Stearns and Koella, 1986; Stearns, 1992). A practical method for examining the lifetime growth curve of a species is the use of size-at-age morphological measurements fitted to algebraic models that use size and age measurements to describe how an individual grows (Ratkowsky, 1983). Growth models can also be used to examine variation in size or age at maturity caused by the environment, and the derived model parameters provide quantitative indices that facilitate comparative analyses. However, when a particular model is chosen in some way independently of the data and used to approximate the growth curve as a basis for inference, uncertainty in the model's selection is assumed to be zero (Burnham and Anderson, 2002). If model selection uncertainty is overlooked, then precision can be overestimated, and the accuracy of predictions will suffer (Burnham and Anderson, 2002). Despite the importance of testing concordance between different growth functions fitted to the same data set (Ratkowsky, 1983), relatively few studies have done so (e.g., Bartareau et al., 2011).

Skull size of the grey wolf (Canis lupus) can vary among populations by gender and geographic range (Jolicoeur, 1959; Clutton-Brock et al., 1994), but little is known about

\footnotetext{
${ }^{1}$ Department of Environment and Natural Resources, Government of the Northwest Territories, PO Box 240, Fort Simpson, Northwest Territories X0E 0NO, Canada; Nic_Larter@gov.nt.ca

2 Department of Biological Sciences, University of Alberta, Edmonton, Alberta T6G 2E9, Canada

3423 Ibis Way, Naples, Florida 34110, USA

(C) The Arctic Institute of North America
} 
the age of completion of development for a particular cranial character. The age of attainment of physical maturity is an important datum, because its variation reflects changes in the nutritional condition of the population, which can influence the social dynamics of wolf packs (Mech, 1999), individual reproductive success (Mech, 2006), and predatory performance (Sand et al., 2006; MacNulty et al., 2009).

In this study, we applied information theory (Burnham and Anderson, 2002) to select the best growth curve in modeling observed skull condylobasal length and zygomatic width as a function of age in wild arctic wolves (Canis lupus arctos). Specifically, we compared four classical alternative growth curves, Gompertz, Logistic, Richards, and von Bertalanffy, for goodness of fit, computational ease, and accuracy in describing size-at-age growth measurements. We then examined the gender-specific growth patterns and ontogeny of sexual size dimorphism in this species revealed by the best model from these alternatives.

\section{METHODS}

As part of a larger study, entire wolf carcasses were collected by local harvesters from Sachs Harbour $\left(71^{\circ} 59^{\prime} \mathrm{N}\right.$, $\left.125^{\circ} 15^{\prime} \mathrm{W}\right)$ on Banks Island between March and October from 1997 to 2002, and from Ulukhaktok (formerly Holman) $\left(70^{\circ} 45^{\prime} \mathrm{N}, 117^{\circ} 42^{\prime} \mathrm{W}\right)$ on northwest Victoria Island between March and June from 1999 to 2002. Muskoxen (Ovibos moschatus) were present in $89 \%$ of 141 stomachs and $90 \%$ of 40 scats. Populations of muskox were large (estimated at 49000-68000 on Banks Island and $18000-19000$ on northwest Victoria Island) during the sampling period (Larter and Nagy, 2001; Nagy et al., 2009), so prey should have been relatively abundant. The occurrence of Peary caribou (Rangifer tarandus pearyi) prey in $5 \%$ or less of stomachs and scats probably reflects the small populations of that species, estimated at 450-1150 and 100-200, respectively, during the sampling period (Nagy et al., 2009).

Skulls were boiled in water without bleach, cleaned of all tissue, and allowed to air-dry for a minimum of 30 days. Jolicoeur (1959) compared grey wolf cranial dimensions and metrical characters and concluded that overall skull size can be satisfactorily described by condylobasal length and zygomatic width. Using calipers, we obtained condylobasal length and zygomatic width measurements (mm) from each skull. Landon et al. (1998) found that layering of cementum in canine teeth was sufficiently accurate for estimating wolf age. The first premolar tooth was extracted from each skull and aged in years by cementum analysis (Matson's Laboratory, LLC, Milltown Montana).

We regressed condylobasal length to zygomatic width to determine whether outliers were present, and we tested for differences between genders in the slope and intercept of cranial measurement relationships. Ratkowsky (1983) described the four candidate growth curves in detail and recommended techniques for obtaining initial parameter estimates in each model. The parameterization of the model used is described below. Equations represent the [1] von Bertalanffy (von Bertalanffy 1957), [2] Logistic (Verhulst 1838), [3] Gompertz (Gompertz, 1825), and [4] Richards (Richards, 1959) growth curves, models $g_{1}$ to $g_{4}$, respectively:

$$
\begin{aligned}
& \text { 1] } A(t)=A_{\infty} \cdot\left[1-\mathrm{e}^{-K(t-T)}\right] \\
& \text { 2] } A(t)=A_{\infty} \bullet\left[1+\mathrm{e}^{-K(t-I)}\right]^{-1} \\
& \text { 3] } A(t)=A_{\infty} \cdot \mathrm{e}^{-e-K(t-I)} \\
& \text { 4] } A(t)=A_{\infty} \cdot\left[1+b \mathrm{e}^{-K t}\right]^{-(1 / m)}
\end{aligned}
$$

where $A$ is condylobasal length (mm) or zygomatic width (mm), $t$ is age (yr), $A_{\infty}$ is asymptotic condylobasal length or zygomatic width of the sampled population, $K$ is a relative growth rate parameter or "maturing index" that describes the rate at which asymptotic condylobasal length or zygomatic width is reached $\left(\mathrm{yr}^{-1}\right), T$ is a fitting constant and is interpreted as the hypothetical age of an individual at zero condylobasal length or zygomatic width assuming the equation to be valid at all ages (yr), $I$ is the age at the inflection point and is described as the theoretical time of maximum growth (yr), and $m$ is a shape parameter determining the position of the inflection point and varies over the range -1 $<m<\infty$. Growth functions were fitted using the LevenbergMarquardt-Nash algorithm (Ratkowsky, 1983).

Each of the growth curves has similar properties (e.g., unweighted nonlinear regressions; sigmoid behavior that describes relative growth rate as a function of asymptotic cranial size; response variable is the expected condylobasal length or zygomatic width for a given age; asymptotic condylobasal length or zygomatic width and maturing index have the same biological meaning), but they differ with an inflection point that is either fixed or flexible (Ratkowsky, 1983). The point of inflection for von Bertalanffy, Logistic, and Gompertz growth models is fixed and occurs at $29.6 \%$ $\left(A_{\infty} \bullet[2 / 3]^{3}\right), 50.0 \%\left(A_{\infty} / 2\right)$, and $36.8 \%\left(A_{\infty} / \mathrm{e}\right)$ of asymptotic condylobasal length or zygomatic width, respectively. The Richards model is a generalized growth curve that encompasses the simpler von Bertalanffy $(m=0.67)$, Logistic $(m$ $=2)$, and Gompertz $(m=\infty)$ models for a particular value of the additional parameter $m$, and the point of inflection is flexible and occurs at any fraction of asymptotic condylobasal length or zygomatic width.

The adjusted proportion coefficient of determination $\left(R^{2}\right)$ and root mean squared standard deviation of data points about a fitted growth curve (SD) were used to evaluate the general goodness of fit and the accuracy of each model to the observed growth pattern, respectively (Sokal and Rohlf, 1995). We used the small-sample, bias-corrected form of the Akaike Information Criterion $\left(\mathrm{AIC}_{\mathrm{c}}\right.$ ) to evaluate and compare the models (Burnham and Anderson, 2002). The model with the smallest $\mathrm{AIC}_{\mathrm{c}}$ value was selected as the best among the models tested. To quantify the plausibility of each model, given the data and the set of four models, the Akaike weight $\left(w_{i}\right)$ of each model was calculated (Burnham and Anderson, 2002). The $w_{i}$ is considered the weight 
of evidence that $i$ is the best of the available set of models. The model-averaged asymptotic condylobasal length or zygomatic width was estimated by averaging the predicted response variable across models, using the corresponding $w_{i}$ as weights (Burnham and Anderson, 2002).

To compare the time of completion of development for condylobasal length and zygomatic width, we assumed that growth virtually ceased at the age when the cranial character reached $97 \%$ of asymptotic size. We used a t-test for independent samples to compare gender differences in the asymptotic condylobasal length, zygomatic width, and maturing index values. All tests were two-tailed and employed an alpha value of 0.05 . Means were expressed \pm SE. Statistical analyses were conducted using Microsoft Excel $^{\circledR}$ and Statistix ${ }^{\circledR} 9.0$ (Analytical Software, 2008).

\section{RESULTS}

There was a linear relationship between condylobasal length and zygomatic width for both females (zygomatic width $=48.51( \pm 29.35)+0.36( \pm 0.12) \cdot$ condylobasal length; $\left.F_{1,25}=8.05, p=0.009, r^{2}=0.419\right)$ and males (zygomatic width $=33.62( \pm 22.15)+0.44( \pm 0.09) \cdot$ condylobasal length; $\left.F_{1,36}=22.57, p<0.001, r^{2}=0.397\right)$, and neither the slope $\left(t_{63}=0.54, p=0.588\right)$ nor the intercept $\left(t_{63}=0.41\right.$, $p=0.681)$ of the skull measurement relationships differed between genders (Fig. 1).

The condylobasal length-at-age and zygomatic widthat-age data were fitted to the von Bertalanffy, Logistic, and Gompertz models without difficulty, and convergence criteria were met after 15 to 25 iterations. Problems were encountered when fitting the Richards model, for which convergence criteria were met only after 230 to 481 iterations.

Each of the four models fitted the condylobasal length and zygomatic width growth curves well for both genders, and fitting degrees $\left(R^{2}\right)$ were $70.1 \%$ or higher (Table 1$)$. The magnitudes in $R^{2}$ ranks among models were, in decreasing order, von Bertalanffy, Gompertz, Logistic, and Richards (Table 1). The von Bertalanffy model had the smallest standard deviation of data points about a fitted growth curve (Table 1), and SD for asymptotic condylobasal length ranged from $\pm 9.33 \mathrm{~mm}$ (or $3.9 \%$ of asymptote) in females to $\pm 10.94 \mathrm{~mm}(4.5 \%)$ in males. The SD for asymptotic zygomatic width ranged from $\pm 4.63 \mathrm{~mm}(3.3 \%)$ in females to $\pm 4.73 \mathrm{~mm}(3.2 \%)$ in males. For both genders and cranial size measurements, the von Bertalanffy model had the smallest $\mathrm{AIC}_{\mathrm{c}}$ and was best supported by the data, with a $w_{i}$ of $37.4 \%$ or more (Table 1). The Gompertz, Logistic, and Richards models were least supported by the data, with $w_{i}$ of $24.5 \%$ or less.

For each growth model, the estimated asymptotic condylobasal length and zygomatic width were larger in males than in females. The corresponding maturing index values were smaller in females than in males (Table 1). The asymptotic condylobasal length and zygomatic width estimates

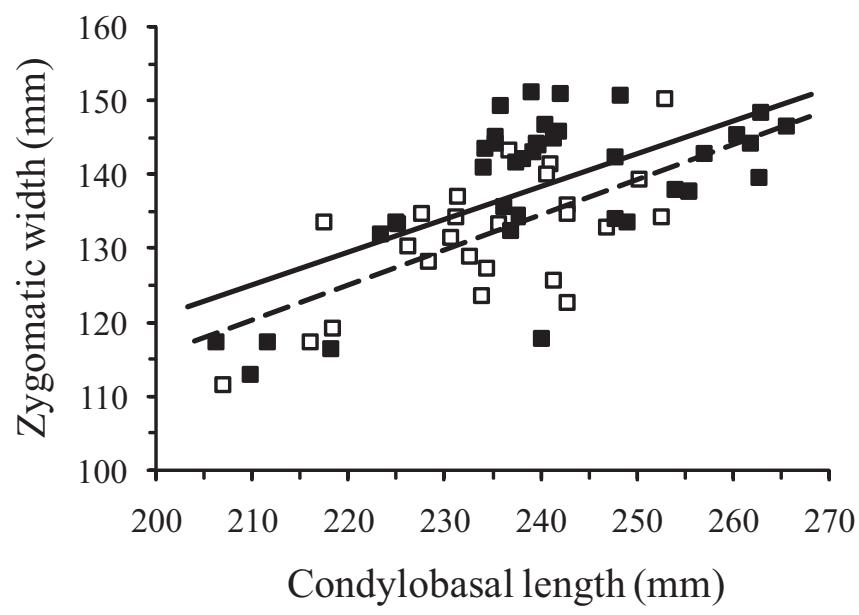

FIG. 1. Relationship between condylobasal length and zygomatic width for female ( $\square$ ) and male (घ) arctic wolves from Banks Island and northwest Victoria Island, Canadian Arctic Archipelago.

for the von Bertalanffy model were larger, and the maturing index smaller, than those estimated by all other models. The asymptotic condylobasal length, zygomatic width, and maturing index estimates for the Gompertz and Logistic model fell between those of other models.

The von Bertalanffy model estimated that both genders reached $97 \%$ and $100 \%$ of asymptotic condylobasal length at age 0.7 and 3 yr, respectively (Fig. 2A). Males reached $97 \%$ of asymptotic zygomatic width at age $1.7 \mathrm{yr}$, about 0.3 yr earlier than females (Fig. 2B). Both genders reached asymptotic zygomatic width by age 9 yr. In males, asymptotic condylobasal length was $3.2 \%$ longer $\left(t_{63}=2.59, p\right.$ $=0.012)$, and zygomatic width $4.1 \%$ wider $\left(t_{64}=2.41, p=\right.$ $0.019)$, than in females. Male maturing index values were $4.1 \%$ larger $\left(t_{63}=0.05, p=0.962\right)$ for condylobasal length, and $32.3 \%$ times larger $\left(t_{64}=1.14, p=0.259\right)$ for zygomatic width, than the values for females.

\section{DISCUSSION}

Growth curves for wolves can differ between genders and populations (Jolicoeur, 1959; Clutton-Brock et al., 1994), and assessing multiple models through a model selection process should delineate which model provides the best representation of observed size-at-age. Our results revealed that the von Bertalanffy growth curve, when used for inferences on the arctic wolf, provided the least biased point estimates of growth in condylobasal length and zygomatic width as a function of age.

Our comparison of four candidate models based on their behavior alone showed that each fit the condylobasal length and zygomatic width growth profiles well, at fitting degrees that exceeded $70.1 \%$. However, model selection based on information theory (Burnham and Anderson, 2002) revealed that the Gompertz, Logistic, and Richards growth models have considerably less support $\left(w_{i} \leq 24.5 \%\right)$ than does the von Bertalanffy model $\left(w_{i} \geq 37.4 \%\right)$. Although 
TABLE 1. Comparison of four candidate growth models for female and male arctic wolves from Banks Island and northwest Victoria Island, Canadian Arctic Archipelago. Estimates $( \pm \mathrm{SE})$ are shown of asymptotic condylobasal length and zygomatic width $\left(A_{\infty}\right)$, and maturing index $(K)$. Also shown are the coefficient of determination $\left(R^{2}\right)$, difference in small-sample, minimum bias-corrected Akaike Information Criterion value of model $i$ in the candidate set $\left(\Delta_{i}\right)$, weight of evidence that model $i$ is the best of the available set $\left(w_{i}\right)$, and root mean squared deviation of data about fitted line (SD).

\begin{tabular}{|c|c|c|c|c|c|c|c|}
\hline $\operatorname{Sex}(n)$ & Model $_{i}$ & $A_{\infty}$ & $K\left(\mathrm{yr}^{-1}\right)$ & $R^{2}$ & $\Delta_{i}^{\mathrm{a}}$ & $w_{i}^{\mathrm{a}}$ & SD \\
\hline \multicolumn{8}{|c|}{ Condylobasal length (mm): } \\
\hline \multirow[t]{5}{*}{ Female (27) } & Bertalanffy & $236.61( \pm 2.15)$ & $5.36( \pm 3.05)$ & 0.877 & 0.00 & 0.399 & \pm 9.33 \\
\hline & Gompertz & $236.60( \pm 2.13)$ & $5.57( \pm 3.16)$ & 0.847 & 1.01 & 0.241 & \pm 9.35 \\
\hline & Logistic & $236.58( \pm 2.12)$ & $5.79( \pm 3.28)$ & 0.796 & 1.03 & 0.238 & \pm 9.37 \\
\hline & Richards & $236.06( \pm 1.96)$ & $6.80( \pm 8.69)$ & 0.701 & 2.36 & 0.123 & \pm 9.41 \\
\hline & Averaged & $236.53( \pm 0.38)$ & $5.69( \pm 0.49)$ & & & & \\
\hline \multirow[t]{5}{*}{ Male (38) } & Bertalanffy & $244.40( \pm 2.02)$ & $5.59( \pm 3.43)$ & 0.893 & 0.00 & 0.374 & \pm 10.94 \\
\hline & Gompertz & $244.37( \pm 2.01)$ & $5.94( \pm 3.65)$ & 0.866 & 1.04 & 0.222 & \pm 10.93 \\
\hline & Logistic & $244.35( \pm 1.99)$ & $6.29( \pm 3.86)$ & 0.822 & 1.09 & 0.217 & \pm 10.93 \\
\hline & Richards & $244.06( \pm 1.93)$ & $7.10( \pm 6.83)$ & 0.742 & 1.39 & 0.187 & \pm 10.91 \\
\hline & Averaged & $244.32( \pm 0.35)$ & $6.10( \pm 0.52)$ & & & & \\
\hline \multicolumn{8}{|c|}{ Zygomatic width (mm): } \\
\hline \multirow[t]{5}{*}{ Female (28) } & Bertalanffy & $139.96( \pm 1.91)$ & $1.07( \pm 0.29)$ & 0.958 & 0.000 & 0.468 & \pm 4.63 \\
\hline & Gompertz & $139.96( \pm 1.91)$ & $1.07( \pm 0.29)$ & 0.925 & 1.338 & 0.240 & \pm 4.64 \\
\hline & Logistic & $139.88( \pm 1.90)$ & $1.13( \pm 0.31)$ & 0.939 & 1.665 & 0.204 & \pm 4.67 \\
\hline & Richards & $139.96( \pm 2.13)$ & $1.07( \pm 0.91)$ & 0.731 & 3.327 & 0.089 & \pm 4.74 \\
\hline & Averaged & $139.94( \pm 0.34)$ & $1.08( \pm 0.14)$ & & & & \\
\hline \multirow[t]{5}{*}{ Male (38) } & Bertalanffy & $145.87( \pm 1.57)$ & $1.58( \pm 0.32)$ & 0.949 & 0.00 & 0.412 & \pm 4.73 \\
\hline & Gompertz & $145.72( \pm 1.52)$ & $1.70( \pm 0.33)$ & 0.898 & 1.04 & 0.245 & \pm 4.74 \\
\hline & Logistic & $145.57( \pm 1.48)$ & $1.82( \pm 0.35)$ & 0.932 & 1.11 & 0.237 & \pm 4.75 \\
\hline & Richards & $145.72( \pm 1.87)$ & $1.70( \pm 1.09)$ & 0.796 & 2.71 & 0.106 & \pm 4.81 \\
\hline & Averaged & $145.75( \pm 0.31)$ & $1.68( \pm 0.16)$ & & & & \\
\hline
\end{tabular}

a The larger the $\Delta_{i}$, and the smaller the $w_{i}$, the less plausible the model $i$.

the fixed point of inflection is one of the potential drawbacks of the three-parameter von Bertalanffy growth model (Ratkowsky, 1983), the failure of estimates for the fourparameter flexible Richards model to be more strongly correlated to data gives some indication of the rational effect of fixing the shape variable in a growth curve.

The von Bertalanffy curve was the first proposed model of animal growth to be based on metabolic laws and on Pütter's idea of balance between the processes of catabolism and anabolism (von Bertalanffy, 1957). In contrast, the generalized Richards model was developed on a merely empirical basis as a theoretical advancement of the von Bertalanffy, Logistic, and Gompertz models, which allows application to both exponential and sigmoid growth curves (Richards, 1959). Although the Richards model is very flexible, some reviewers have advised that it not be used because it includes an additional shape parameter that has no obvious biological interpretation (Ratkowsky, 1983) or because its parameters exhibit significant colinearity and are sometimes numerically unstable (Zeide, 1993). Our analyses revealed problems of convergence for the Richards model that resulted in difficulties in fitting the data. Conversely, the von Bertalanffy growth model incorporates fewer parameters, but all are derived directly from metabolic laws; there is less covariance between the parameters; our initial parameter estimates were easily obtainable; and we did not observe any convergence problems.

The asymptote and maturing index values are estimates based on the data at hand and can vary considerably if data are not representative of the full range of conditions to which the species may be subjected through successive seasons or years or over entire growth cycles. In all growth analyses, it is assumed that the range of the data is adequately dispersed across the entire curve; otherwise, inaccurate and misleading extrapolations result (Ratkowsky, 1983). The wide range of ages used to develop our growth models should have reduced any bias associated with limited sampling. Therefore, we are confident that the genderspecific von Bertalanffy condylobasal length-at-age and zygomatic width-at-age growth models are biologically correct and reflect the lifetime interaction between a wolf's genetics and its environment and the effect of this interaction on the wolf's growth and maturation.

The von Bertalanffy model accounted for $87.7 \%$ or more of the variation in gender- and age-specific condylobasal length and zygomatic width growth profiles. High model performance for condylobasal length-at-age and zygomatic width-at-age data is logical because it is a reliable measurement that represents growth of the inflexible skeleton. However, the remaining variability indicates that other factors that are independent of age and were not included in the model might also have affected the growth of wolves. These could include factors such as individual and temporal variation in growth rates. A non-age factor such as individual variability may cause part of the observed variation in growth of wolves. A variety of different prey resources can be found within the area occupied by a study population (Pimlott, 1967; Kuyt, 1972; Wiebe et al., 2009). In 

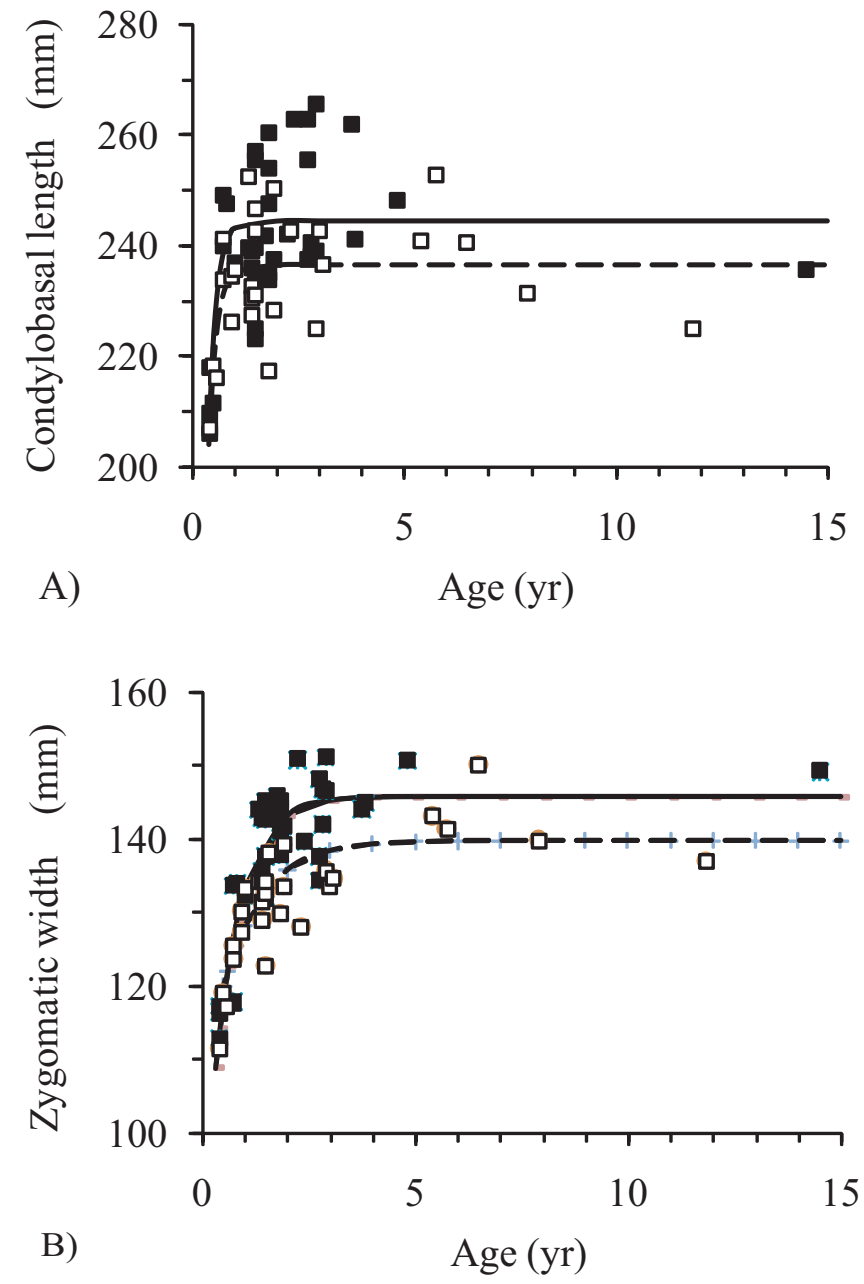

FIG. 2. Skull condylobasal length and zygomatic width by age in female ( $\square$ ) and male (घ) arctic wolves from Banks Island and northwest Victoria Island, Canadian Arctic Archipelago: A) condylobasal length and B) zygomatic width. Fitted lines reflect growth curve for females (dashed line) and males (solid line) as calculated from the von Bertalanffy function.

such a scenario, one would expect individual variation in growth rate across a population. Thus, we maintain that our von Bertalanffy model parameter estimates are reliable for the observed biological data that they were explaining and that they accurately depict the gender-specific condylobasal length and zygomatic width growth patterns of the arctic wolf.

The growth models revealed that both sexes grew most rapidly during the early postnatal period and that most of a wolf's lifetime was spent near asymptotic size. In both genders, the growth models estimated that $97 \%$ of the asymptotic condylobasal length was reached at age $0.7 \mathrm{yr}$, a time shortly before juveniles are known to hunt with adults (0.8 yr: Mech, 1974; Halfpenny, 2003) and disperse from the pack (0.8 to 1 yr: Mech, 1974; Gese and Mech, 1991), and before the epiphyseal cartilage calcifies (1 yr: Rausch, 1967). A general linear mixed model of body mass growth by MacNulty et al. (2009) also noted an initial breakpoint at 0.75 yrs for both genders. Both genders were estimated to reach the asymptotic condylobasal length at age $3 \mathrm{yr}$, which matched the time when most wolves attain sexual maturity and mate (3 to 3.8 yr: Mech, 1974; Medjo and Mech, 1976).

The growth models also revealed that both genders grew in zygomatic width for a longer time than they grew in condylobasal length. The maturing index values for zygomatic width were only $19 \%$ to $28 \%$ of those for condylobasal length, indicating that any fraction of growth in skull width was reached later than the same fraction of length. Prolonged growth in zygomatic width relative to condylobasal length is most likely to be associated with enlargement and improvement of surfaces for origin of jaw musculature, specifically, the temporalis, masseter, and pterygoideus muscles (Ewer, 1973). Males and females were estimated to reach $97 \%$ of the asymptote zygomatic width at age 1.7 yr and 2 yr respectively, a time coinciding with the period when individuals typically reach puberty (1.8 years: Mech, 1974; Halfpenny, 2003) and attain most of their mass $(>1$ to 2 yr: Ballard et al., 1997; Mech, 2006; MacNulty et al., 2009). Both genders reached asymptotic zygomatic width by age $9 \mathrm{yr}$, which is about the reported lifespan of wild wolves (10 to $13 \mathrm{yr}$ : Mech, 1974, 1988), suggesting that wolves may continue to grow in skull width throughout their life.

The skulls of arctic wolves showed sexual size dimorphism. Asymptotic size estimates indicate that in males, condylobasal length was $7.8 \mathrm{~mm}(3.2 \%)$ longer, and zygomatic width $5.9 \mathrm{~mm}(4.1 \%)$ wider, than in females. This finding supports the earlier observation that male skulls are about $4 \%$ longer and wider than those of females (Jolicoeur, 1959). However, the asymptotic size estimates were not the largest observed condylobasal length or zygomatic width attained by any individual in the population; instead, they represent the mean maximum size attained in the population at maturity, as argued from metabolic laws (von Bertalanffy, 1957). Possible explanations for this male-biased sexual size dimorphism may be that male pups start larger (Van Ballenberghe and Mech, 1975), grow faster, grow for a longer time during life, or use a combination of these strategies (Southwood, 1988).

With regard to pup size, Hillis and Mallory (1996a) found no significant sexual size dimorphism in body mass or other morphological features of wolf fetuses between day 32 after coitus and parturition. Van Ballenberghe and Mech (1975) reported that the mean weight of male pups captured during specific periods was generally greater than that of females, but some females exceeded the standard curve for males. We found that individual variation in age-specific growth in condylobasal length and zygomatic width was greater than differences due to sex among the youngest offspring to about age $0.5 \mathrm{yr}$. This result indicates that both sexes grew at the same rate during this early juvenile period because more rapid growth must occur for one sex to reach a larger size than another of the same age. However, there was well-defined male-biased sexual size dimorphism by age 0.6 yr. Thus, the fact that from about age 0.5 a male ultimately grew to somewhat larger asymptotic condylobasal length and zygomatic width than a female the same age 
revealed that during that period, males must have had a greater absolute rate of growth than females. Adult teeth, which are designed to tear and cut large chunks of meat and to crush bone, typically replace deciduous teeth by age 0.5 yr (Mech, 1974). Therefore, the proximate cause of sex differences in the rate of skull growth apparently begins to operate after juvenile wolves attain their adult teeth and continues to adulthood.

Our growth models revealed that male skulls grew larger than female skulls both before and after female sexual maturity. This type of growth pattern is often indicative of sexual selection that acts to produce larger body size, which benefits more competitive males in terms of increased reproductive success, particularly males of polygynous species that breed with several females residing in their home range (Stearns and Koella, 1986). However, Mech (1999) found that the typical wolf pack is a family, with the adult parents guiding the activities of the group in a division-oflabor system in which the female predominates primarily in such activities as pup care and defense and the male primarily during foraging and food-provisioning. All young wolves in a pack are potential breeders, and when individuals do breed, they automatically become alphas. Alpha males and females were merely the breeding animals of the pack, and dominance contests with other wolves were rare, if they existed at all (Mech, 1999). Hillis and Mallory (1996b) concluded that sexual dimorphism in wolves has evolved primarily as a foraging strategy, owing to division of labor between the sexes: males are more highly specialized for capturing and killing large ungulate prey, while females are more specialized for a nurturing role.

Jolicoeur (1959) concluded that wolf skulls differ in size among dispersed populations, with zygomatic width increasing and condylobasal length decreasing as latitude increases. Factors of the environment in which local populations live, such as day length or climatic conditions (Jolicoeur, 1959) and diet (Ewer, 1973), may influence skull development. We assume that growth in the cranial features is related to development of the skeletal and muscle structures associated with capturing prey and feeding. Wolves kill prey by biting and shaking it, breaking the back, or disabling the victim with bites to the legs and venter. Difference in body size of the grey wolf is thought to explain variation in predatory performance and might influence prey selection (Sand et al., 2006; MacNulty et al., 2009). In fact, prey specialization may influence patterns of gene flow in wolves of the Canadian Northwest (Carmichael et al., 2001), and thus it might also cause geographic variation in wolf skulls. It will be interesting to determine whether geographic variation in skull size, growth, and musculature relate to differences in diet and growth patterns among populations by prey specialization.

In conclusion, the von Bertalanffy growth curve was the most suitable model to describe condylobasal length-at-age and zygomatic width-at-age growth patterns of the arctic wolf because it was easy to fit, with higher fitting degrees, lower root mean squared standard deviation of data points about a fitted growth curve, larger Akaike weight, and fewer parameters derived directly from metabolic laws used to estimate gender-specific growth patterns. In males, asymptotic condylobasal length was 3.2\% longer, and zygomatic width $4.1 \%$ wider, than in females. Sexual size dimorphism in this species develops in part through faster growth of males, which might benefit them in terms of reproductive success and the capture and killing of large ungulate prey.

\section{ACKNOWLEDGEMENTS}

We thank the local harvesters from Sachs Harbour and Ulukhaktok (formerly Holman) who provided carcasses. Special thanks to Mark Ekotak, who assisted with the logistics of samples from Ulukhaktok, and to Lizz Gordon and Norman Snowshoe, who assisted with skull preparation and measuring. Matson's Laboratory aged the teeth. The Government of the Northwest Territories and the Inuvialuit Land Claim Wildlife Studies Implementation Fund provided funding for the work. We also thank Linda Pulliam for diligence in sourcing literature and the anonymous reviewers for their constructive and insightful comments on this manuscript.

\section{REFERENCES}

Analytical Software. 2008. Statistix 9.0. Tallahassee, Florida: Analytical Software.

Ballard, W.B., Ayres, L.A., Krausman, P.R., Reed, D.J., and Fancy, S.G. 1997. Ecology of wolves in relation to a migratory caribou herd in Northwest Alaska. Wildlife Monographs 135. 47 p.

Bartareau, T.M., Cluff, H.D., and Larter, N.C. 2011. Body length and mass growth of the brown bear (Ursus arctos) in northern Canada: Model selection based on information theory and ontogeny of sexual size dimorphism. Canadian Journal of Zoology 89:1128-1135.

Burnham, K.P., and Anderson, D.R. 2002. Model selection and multimodel inference: A practical information-theoretic approach. New York: Springer-Verlag.

Carmichael, L.E., Nagy, J.A., Larter, N.C., and Strobeck, C. 2001. Prey specialization may influence patterns of gene flow in wolves of the Canadian Northwest. Molecular Ecology 10:2787-2798.

Clutton-Brock, J., Kitchener, A.C., and Lynch, J.M. 1994. Changes in the skull morphology of the arctic wolf, Canis lupus arctos, during the twentieth century. Journal of Zoology 233:19-36.

Ewer, R.F. 1973. The carnivores. Ithaca, New York: Cornell University Press.

Gese, E.M., and Mech, L.D. 1991. Dispersal of wolves (Canis lupus) in northeastern Minnesota, 1969-1989. Canadian Journal of Zoology 69:2946-2955.

Gompertz, B. 1825. On the nature of the function expressive of the law of human mortality, and on a new mode of determining the value of live contingencies. Philosophical Transactions of the Royal Society of London 115:513-585. 
Halfpenny, J.C. 2003. Yellowstone wolves in the wild. Helena, Montana: Riverbend Publishing.

Hillis, T.L., and Mallory, F.F. 1996a. Fetal development in wolves, Canis lupus, of the Keewatin District, Northwest Territories, Canada. Canadian Journal of Zoology 74:2211-2218.

1996b. Sexual dimorphism in wolves (Canis lupus) of the Keewatin District, Northwest Territories, Canada. Canadian Journal of Zoology 74:721 - 725 .

Jolicoeur, P. 1959. Multivariate geographical variation in the wolf Canis lupus L. Evolution 13:283-299.

Kuyt, E. 1972. Food habits and ecology of wolves on barrenground caribou range in Northwest Territories. Canadian Wildlife Service Report Series No. 21.

Landon, D.B., Waite, C.A., Peterson, R.O., and Mech, L.D. 1998. Evaluation of age determination techniques for gray wolves. Journal of Wildlife Management 62:674-682.

Larter, N.C., and Nagy, J.A. 2001. Calf production, calf survival, and recruitment of muskoxen on Banks Island during a period of changing population density from 1986-99. Arctic 54(4):394-406.

Lawrence, T.L. 1980. Growth in animals. Woburn, Massachusetts: Butterworth Publishers Inc.

MacNulty, D.R., Smith, D.W., Mech, L.D., and Eberly, L.E. 2009. Body size and predatory performance in wolves: Is bigger better? Journal of Animal Ecology 78:532 -539.

Mech, L.D. 1974. Canis lupus. Mammalian Species 37:1-6. 1988. The arctic wolf: Living with the pack. Stillwater, Minnesota: Voyageur Press.

1999. Alpha status, dominance, and division of labor in wolf packs. Canadian Journal of Zoology 77:1196-1203.

—. 2006. Age-related body mass and reproductive measurements of gray wolves in Minnesota. Journal of Mammalogy 87:80-84.

Medjo, D.C., and Mech, L.D. 1976. Reproductive activity in nine- and ten-month-old wolves. Journal of Mammalogy 57:406-408.

Nagy, J.A., Larter, N.C., and Wright, W.H. 2009. Population estimates for Peary caribou (Minto Inlet Herd), Dolphin and
Union caribou, and muskox on Northwest Victoria Island, NT, July 2001. Manuscript Report 202. Yellowknife: Department of Environment and Natural Resources, Government of the Northwest Territories.

Pimlott, D.H. 1967. Wolf predation and ungulate populations. American Zoologist 7:267-278.

Rausch, R.A. 1967. Some aspects of the population ecology of wolves, Alaska. American Zoologist 7:253-265.

Ratkowsky, D.A. 1983. Nonlinear regression modeling: A unified practical approach. New York: Marcel Dekker.

Richards, F.J. 1959. A flexible growth function for empirical use. Journal of Experimental Botany 10(29):290-300.

Sand, H., Wikenros, C., Wabakken, P., and Liberg, O. 2006. Effects of hunting group size, snow depth and age on the success of wolves hunting moose. Animal Behaviour 72:781-789.

Sokal, R.R., and Rohlf, F.J. 1995. Biometry, $3^{\text {rd }}$ ed. New York: W.H. Freeman and Company. 887 p.

Southwood, T.R.E. 1988. Tactics, strategies and templets. Oikos 52:3-18.

Stearns, S.C. 1992. The evolution of life histories. Oxford: Oxford University Press.

Stearns, S.C., and Koella, J.C. 1986. The evolution of phenotypic plasticity in life-history traits: Predictions of reaction norms for age and size at maturity. Evolution 40:893-913.

Van Ballenberghe, V., and Mech, L.D. 1975. Weights, growth, and survival of timber wolf pups in Minnesota. Journal of Mammalogy 56:44-63.

Verhulst, P.F. 1838. Notice sur la loi que la population suit dans son accroissement. Correspondance mathématique et physique 10:113-121.

Von Bertalanffy, L. 1957. Quantitative laws in metabolism and growth. The Quarterly Review of Biology 32:217-231.

Wiebe, N., Samelius, G., Alisauskas, R.T., Bantle, J.L., Bergman, C., de Carle, R., Hendrickson, C.J., Lusignan, A., Phipps, K.J., and Pitt, J. 2009. Foraging behaviours and diets of wolves in the Queen Maud Gulf Bird Sanctuary, Nunavut, Canada. Arctic 62(4):399-404.

Zeide, B. 1993. Analysis of growth equations. Forest Science 39:594-616. 